\title{
How Learned Are Our Lessons?
}

\author{
Mónica Pinto
}

... the Constitution is not a set of rules to maximize individual welfare on some global scale. Rather, it is a statement about how a society wishes to organize itself ... ${ }^{1}$

On 19 March 2O2O, the World Health Organization (wHO) declared that the coronavirus disease 19 (COVID-19) had become a pandemic.

As in the movies, the cacophony started muting, the usual movements slowed down progressively and, finally, stopped. No human voices, no engine noises, silence. The world came to a lockdown that was strictly enforced for $60 /$ 75 days. Borders and skies were closed. For a short while, conflicts, especially armed conflicts, were put between brackets. Words like confinement, social distancing, essential and non-essential sectors, among others, invaded our everyday lives.

The situation was so unprecedented that world leaders lacked a specific language to deal with it. Some of them looked at what they considered to be the most difficult scenario. Suddenly, we were at war.

President Donald Trump of the United States identified himself as a wartime president. President Emmanuel Macron announced that France was at a sanitary war. Also, Prime Minister Boris Johnson of the United Kingdom invoked wartime language in the fight against coronavirus. In his first appearance

1 Owen Fiss, "The Immigrant as a Pariah" in A Community of Equals (New Democracy Forum, 1999) 17 
during the pandemic, President Daniel Ortega of Nicaragua explained that he had been waging the battle against the CoviD-19.

The (natural) reaction was to put in place wartime measures. Even curfew was declared in many countries or in given cities. Ban on travel to and from certain countries and then, shutdown on flights and road transportation followed.

No more personal decisions. Family and social meetings were forbidden because of the risk of infection. Same regarding your elders, your sons and daughters, grandchildren, best friends. No medical appointments except for Covid-19 reasons. Stay at your place, do not socialize.

\section{$2 \quad$ Authoritarian Approaches to Deal with the Pandemic}

The reactions to the pandemic have been more or less alike all over the world, with no great differences regarding the level of development or the democratic tradition of the community.

Fear permeated national societies and the field was open for governments to take measures to suspend basic rights, sometimes in the light of the requirements put forward in constitutions and human rights treaties, and others, avoiding them.

The general perception is that more rights than those strictly needed have been put between brackets in many societies, and lockdown measures have been extended not necessarily on the grounds of the pandemic.

In some countries, the confinement reached the state and it resulted in no legislative activity, no judicial work, only the executive branch continued operating and concentrating the highest level of power ever in democratic regimes. Believe it or not, judicial activity was not considered an essential sector by some governments.

The crisis became all powerful and omnipresent. It could provide support to any decision. Personal freedom and human rights looked like the obstacles that the liberal society advanced against the measures that the crisis imposed.

Authoritarian approaches have been prevalent. They conveyed the message that democracy, liberal democracy, deliberative democracy, cannot cope with the situation. Confinement, an interim measure which would help governments to refurnish their health facilities and to stop the circulation of the disease, was imposed as if it were a medical treatment.

Soon after the wHo proclamation, in some places, the pandemic and the confinement became two different, even unrelated, matters. The first burst one day and the world started a frenetic race to control it; the latter was imposed 
by local rulers initially on the grounds of the pandemic but then was extended on unclear grounds.

When human rights permeated the legal order and also medical sciences, some approaches changed. The pattern became the full capacity both in law and in health terms. Nowadays, the rule is that all human beings, with or without disabilities, should have full enjoyment of all human rights on an equal basis. Accordingly, for instance, measures of compulsory hospitalization in asylums are the exception to the rule, an exception that has to be supported on the grounds that there is no other less intrusive measure available for the case and able to produce analogous results.

The impact of human rights on medical treatments was measured in democratic terms. In that line, the rule of the full capacity of all human beings came hand in hand with the concept of informed consent, which imposes on medical professionals the duty to refrain from exercising paternalistic control and instead provides patients with the information necessary for them to decide which course of action to adopt.

All these achievements have been neutralized by the authoritarian decisions adopted during the pandemic. Initially, only epidemiological reasons supported decisions by public authorities. However, science driven decisions do not necessarily meet human rights criteria. Soon these decisions had to be nuanced in light of other considerations, including those emerging from the field of mental health.

Discrimination, anti-Semitism, racism, which had been decently managed, if not completely superseded long ago, found room in everyday life. As an example, a relatively good quality of life had turned racism invisible in the American landscape but it flourished with the murder of George Floyds. Fortunately, the situation also made room to the Black Live Matter movement.

Different kinds of violence - social violence, gender violence, violence against children, LGBTIQ+, indigenous peoples - increased all over the world. Victims of violence have been confined together with their aggressors. Home had become a cage. Conventional wisdom as well as empirical evidence revealed that the great majority of domestic violence victims are aggressed by their relatives or persons of their inner circle. However, that was ignored when deciding the scope and the extent of confinement measures in a great number of places.

The pandemic highlighted, once again, the role of women as unpaid care workers. Gender approaches have been generally absent in the pandemic, producing lots of sensitive situations that could have been avoided had women participated in the decision-making process. We are not part of the problem but part of the solution. 
These emergency situations scarcely met the requirements set forth in international human rights treaties and only a bunch of States fulfilled the information duty provided for in such treaties.

\section{Equality as the First Victim of the Pandemic}

The uniqueness of the situation is unprecedented. Never before had the world been in pause as it was during the COVID-19 pandemic.

Even when some may still think that there is no such a thing as globalization, narratives challenging globalization were faced with the resounding evidence of its existence because of CoviD-19.

This is the first time ever that a phenomenon has taken place all over the world, almost at the same time, in every single country. CoviD-19 reached poor and rich countries, little and big States, powerful and powerless communities. It also reached the superpower and the head of its government and also those coming next in line.

Chilean President Ricardo Lagos used to say that globalization means a qualitative change regarding the way in which our countries establish their ties with the international life. ${ }^{2}$ The debate is not whether there is globalization but instead how globalization may help to reduce poverty and asymmetries.

Equality, which is always struggling to have its existence acknowledged, was the first victim of this pandemic. This global situation stresses the inequalities among countries and among people. CoviD-19 affects the rich and the poor, but the rich can survive better than the poor.

The legal and political order in force after the Second World War made a pledge regarding the equal rights of men and women and of nations large and small and the United Nations supported the principle of the sovereign equality of all its members.

Equality is, perhaps, the most revolutionary feature of the notion of human rights, one of the most important inventions of our civilization. ${ }^{3}$ Even when nothing is more diverse than two human beings, we are all equal as rightsholders, because of a legal decision. That being said, it is not that (liberal notion of) equality that I am targeting here but a structural equality, one that incorporates historical and social data, which acknowledges the subjugation and systematic exclusion that affects wide sectors of society, including women.

2 Ricardo Lagos Escobar, 'Ética y Globalización’ (1999-200o) Revista Jurídica de Buenos Aires 183,184 .

3 Carlos Santiago Nino, Ética y Derechos Humanos (2 edn, Astrea 1989) 1. 
Structural equality has been a pending issue in many parts of the world, including the Latin American and Caribbean region. The pandemic is having tremendous impact on equality. The countries showing high levels of structural inequality should seriously consider dealing with it before it becomes irretrievable.

It is not an arithmetic rule but, generally, structural inequality coexists with structural poverty. A poverty that is much more than an insufficient quantity of resources to get a basic basket of goods and services to be able to live with dignity. It is not a purely economic question. Structural poverty prevents from reaching human development and it entails vulnerability and social exclusion. Poverty requires a human rights approach, an approach acknowledging that the poor are human beings, rights-holders on an equal footing with the rest of the society.

People in vulnerable situations, usually living under the threshold of poverty, now have less hope than before the crisis. The informal economy where they find a way of earning a life is more fragile. Those living on the edge between poverty and marginality have become extremely poor and have to make their lives as they can when they can. The tragedy of these people is that they are caught between a rock and a hard place because if they are confined, they do not get money and they die of hunger but if they are not, they die from COVID-19.

Migrants and refugees have been abandoned to their fate in highly developed countries of the world. Those traditionally in vulnerable situation, like indigenous peoples and/or LGBTIQ+, have a harder life now.

Only recently the WHO acknowledged how confinement impacts on poverty. States should stop turning a blind eye to poverty. Redress is needed before the next pandemic.

\section{A Global Health Problem Looking for a Universal Approach}

The United Nations General Assembly Resolution 74/270 of 3 April 2020 considered that the CoviD-19 pandemic poses a threat to human health, safety, and well-being. Maybe this statement is too narrow given the wide array of issues that the pandemic affects.

In any case, situations like the present one challenge a government's ability to fulfil its obligations of protection in the field of public health while ensuring respect for human rights under its jurisdiction.

The pandemic revealed the weakness of health plans and medical facilities all over the world. Europe, which used to have a more than reasonable public 
health policy, could not afford the number of patients and their treatments. The US President Trump decided to rebrand the Affordable Care Act, also known as Obamacare, and issued an Executive Order on An America-First Healthcare Plan without getting into details and having as backdrop the incredibly high number of casualties of the Covid-19 in that country. Latin America had to put in place a decent scheme to face the crisis, and the same problems arise in Africa, perhaps with more difficulties, and Asia.

The focal point is the World Health Organization, a United Nations specialized agency, a technocratic organization with the capacity to produce and enforce international health regulations. It manages the right to health but also has to develop the capacity of predicting gaps in the rules and to ensure that they are duly filled. At the same time, it is not expected to be reckless in its statements. It is said that the wHO was disclosing the public health emergency in a timely manner and then, the pandemic. It acted on the grounds of serious scientific knowledge. As Jan Klabbers put it in a recent article, "the wHO is engaged in a host of non-binding highly authoritative forms of exercising public authority".

The reactions to the wHO's statements are not attributable to the organization but to the States, among which those that still today challenge the idea of health care as a public policy.

\section{$5 \quad$ Is the Pandemic a Turning Point for International Law?}

The CoviD-19 crisis is more global than the Second World War but it has not reached the same global consequences. It does not look as though it is a turning point in the framework of international relations.

International law will stay there, States will remain as the main actors in this field and Article 38 of the Statute of the International Court of Justice will not be rewritten because of this crisis.

As evidence that there have been no major changes, President Nicolás Maduro of Venezuela reacted to the declaration of the pandemic saying that COVID-19 is a disease of wealthy people created by the US; in turn, in the US, it was said that it was created in a Chinese laboratory, and vice-versa. No changes.

That being said, it does not mean that everything will be as it used to be. The world will have to deal with the 6o million people pushed to poverty because

4 Jan Klabbers, 'The Second Most Difficult Job in the World. Reflections on COVID-19' (2020) 11(2) Journal of International Humanitarian Legal Studies 270. 
of the pandemic and the shutdown of advanced economies, as warned by the World Bank. ${ }^{5}$

This pandemic showed its global nature and that we need a global exit. We cannot get out of this individually. Perhaps some States will, but surely not the great majority. Multilateralism and international co-operation are two of the traditional avenues that are available to enhance the quality of global solutions. A more robust World Health Organization is needed. Its prevention programs and thresholds should be strengthened.

Relying on the scientific information managed by wHo, we should be prepared to face public health emergencies of international concern more frequently in the future. The pandemic revealed itself as a negative global common. As it happens with other global commons, we need international co-operation to deal with them. All have to be onboard. A universal health coverage is needed.

To be both effective and sustainable, the policy responses adopted need to include public agencies and the private sector as main actors of the prevention. A prevention that means universal access to vaccines and medical treatment but also to tap water and sewerage.

In the 1970s, the instruments of the New International Economic Order called upon developed States to act in solidarity with those in development of the Third World. The approach was not successful. However, at the end of the 199os, when the hole in the ozone layer was an irreversible fact, developed and developing States found the way to establish a partnership which made room for shared but differentiated responsibilities. All had to be onboard. Same here.

As lessons learned from this ongoing crisis, both the rule of law and a human rights approach should lead to the wisest decisions. As in other matters, like artificial intelligence, ${ }^{6}$ here too States have the duty to respect our human rights and to avoid arbitrary interference in their exercise. Human rights perform as hermeneutic tools that help in decision-making process. The pro persona principle should prevail when determining the proper restriction to our rights that is necessary in a democratic society.

As stated earlier in this paper, science driven decisions do not necessarily meet human rights criteria. Keeping people in confinement may be a tool to prevent diseases but at the same time it has serious implications in the

5 Jonathan Wheatley, 'Virus will push up to 6om into extreme poverty, World Bank warns' (Financial Times, 19 May 2020) <https://www.ft.com/content/85882871-1b61-49e2-b17o -cc3fi5gb8f88 > accessed 2o April 2021.

6 Daragh Murray, 'Using Human Rights Law to Inform States' Decisions to Deploy AI' (2020) 114 AJIL Unbound 158. 
development of other human capacities and skills as well as in other fields of activities.

I am aware that the argument cuts both ways. Let's consider climate change. We should pay attention to what science and scientists have to tell us so as to prevent more degradation. But in order to do so, we have to engage in a serious conversation on the search for appropriate balances. A democratic debate on the goals that are pursued, the scope of the eventual intervention and the means used to that end is necessary.

The international law agenda has to include these conversations. We are, indeed, facing complex and busy times. 